\title{
CONCEPTS OF RECEPTIVITY AMONG THE RECITERS OF ABU TAMMAM AND AL-MUTANABI IN THE BOOK OF THE ORDER BY IBN AL-MUSTAFY AL-ARBLI (D.637 AH)
}

\author{
Abstract research for a PhD thesis by student Mona Muhammad Hatem \\ Under the supervision of Prof. Dr. Nuri Kazem Amnesif Ali \\ University of Baghdad / Ibn Rushd College of Education for Human Sciences the department of Arabic language
}

\begin{abstract}
The book of the system by Ibn al-Mastufi Al-Arbli came to fulfill many of the readers of the poetry of Abu Tammam and Al-Mutanabi. Waiting between the recipient and the text,the text was more aesthetic and more open to a number of readings, and these concepts can be relied upon in reading the poetry of Abi Tammam and AlMutanabi. Concepts of receiving according to the reciters of Abu Tammam and Al-Mutanabi in the book of the order by Ibn Al-Mustufi Al-Arbli (d.637 AH). Hans Robert Yaus based the theory of receptivity on several concepts which will be explained accordingly.
\end{abstract}

Article Received: 10 August 2020, Revised: 25 October 2020, Accepted: 18 November 2020

First: The Expectation Horizon or (Waiting Horizon):

This concept was not new to Yaws, but rather an interrogation of Gadimir's concept of historical horizon (). Gadimir employed it to "indicate with it the extent of the vision that includes everything that can be seen from a particular location".The term horizon was a common concept in German philosophical circles, which Karl Boyer and Karl Mannheim adopted as a complex - the horizon of expectations - long before Yeos, and the concept of the horizon of expectations was previously associated with cultural affairs (), as art historian A.H. Jambrish in his book (Art and Illusion) "A mental device that records deviations and modifications with extreme sensitivity."

The concept of the horizon of expectation of Yaws is related to the recipient, as it "represents the space through which the process of constructing meaning and drawing the central steps of analysis and the role of the reader in producing meaning through literary interpretation which is the focus of pleasure and its corridor in the aesthetic of receptivity, as what was the linguistic medium is the focus and corridor of pleasure for the builders ".

The horizon of expectations is the tool that links two active elements of culture: history and the incidents and linguistic patterns it contains, aesthetics and the references it contains, and ideas. Hafez Aliwi believes that "the horizon of expectations is a link between history and aesthetics, that is, between Formalism and Marxism ".
Yaws has turned to three factors, through which the horizon of expectation can be achieved, which will appear as follows:

1- There must be experience among the audience regarding the literary genre to which the text belongs.

2- It is essential to know the form and content of previous texts and the extent of their restrictions in the new text.

3- The existence of a conflict between the imaginary world, that is, between poetic language on the one hand, and reporting language on the other.

However, the horizon of expectation, according to Starobansky stipulates that "it requires those who apply it to be at the level of knowledge of a jurist historian in language who is skilled in careful formal analyzes of shifts and changes. For the rushing beginners "().

No reader can discover the horizon of the text as it is necessary for a reader who is armed with culture, who has experience in the gender of the text, the structure of text construction, as well as has experience with the writer's previous texts and his style in order to allow him to explore the text and whether his horizon corresponds to the horizon of the text if the text carries within its techniques that he knows Reader previously. And when there is no consensus, the text shocks the receiver with unexpected techniques and methods for the reader. 
The effectiveness of the forecast horizon can be viewed in the book The System by:

A- Response between the recipient's horizon and the text

It is the compatibility or congruence between the recipient's expectations about the text and what the text contains. Hence, a congruence emerged between the horizon of al-Kharzanji and the horizon of the text of Abu Tammam who said:

The steps of the days are preceded by its life It went on to become a backrest

Al-Kharrazinji said: "(Its life): it is not a life of revelation, and (the Musnad) is the age. He says: The life of these endeavors and their old ones preceded the beginning of the age. That is, they are older than the age, and the age after it became a description assigned to it. It became (meaning: it remained: the language of folding).

Al-Kharzanji's expectations for what he was expecting from the text of Abu Tammam, for this reason, coincided with the meaning of the words contained in the text.

This text also responded to the expectations of Abu Zakaria, explaining the intended meaning of the text of Abu Tammam by saying: "(Her life): its old. And (distraction) in (her life) is due to the efforts of al-Majdouh in order to defeat the ages, that is, she is old and this is in the meaning of exaggeration and it is permissible to be (the Musnad) ) In other than the rhyme, the meaning of the hadith that is attributed to men, that is, these endeavors have become a hadith supported by time ... and narrated (preceded by the eternity) ".

Another reciter, Al-Marzouki, coincided with the horizon of Al-Kharasanji and Abu Zakaria. And his reading was a summary of them, and this appeared in his saying: "It is permissible to raise (its umrahs) and set them up: The eternity. And from the imposter, it made (the age) a mistake, that is, the old one. From the mistakes of the days preceded the endeavors of this " $j$

The text of Abu Tammam did not deviate from the expectations of Al-Kharazanji, Abu Zakaria, and Al-Marzouki, so it was compatible in form and substance with what is in the minds of the readers.

The compatibility of the horizon with the text appears: in Abi Al-Fath's response to $\mathrm{Al}-$ Mutanabbi's saying:

If it reigned over the hearts, then it did

The reign of time with its land and sky()

He said in his readings of this text: "That is, this beloved is not like other beloved loved ones, but he loves this because of the majesty of his destiny and the sublime of his matter, for he has reigned over the hearts, that is, if he has possessed the earth and the sky, then it is not surprising that he possesses the hearts and exaggerates the mention of the sky, as if it is the saying of al-Farazdaq:

\section{We took the horizons of the sky upon you \\ We have moons and horoscopes \\ Similarly, he said in it: \\ If I had no convincing lover \\ I apologize, but from a sterilized lover} mentioned.

He made him a darling in the way that I

Ibn Jinni set forth to explain the meaning of the text from previous texts bearing the same meaning as the text of al-Mutanabi, and he cited them. This text was identical to the horizon of its expectation, and the response took place between its horizon and the text.

The horizon of al-Wahid's expectation is similar to Ibn Jinni in saying: "That is, if he is an owner of the hearts with his love, then he is the possessor of time and spends it according to what he wants, and exaggerates the mention of the earth and the sky, and he added to time, because time differs and rotates between the earth, the sky and the $\mathrm{Ba}$ in his land meaning (with).", Al-Wahidi did not come out with a reading different from that of Ibn Jinni, and he did not find in the text what was outside his expectations, so there was a response between the horizon of his expectation and the horizon of the text.

The horizon of al-Akbari also coincided with that of Ibn Jinni's expectation, although alAkbari bore the meaning in three ways:

The first aspect: he meant that the love of Seif al-Dawla (the beloved) was limited to his giving and his courage.

The second aspect: that his love was limited to satisfying the people of time with good management.

The third aspect: He satisfied the creation and the Creator until it satisfied the people of Heaven.

These three aspects appeared in his saying: "There are three aspects in the meaning, one of them: that this beloved, who is the sword of the state, was not limited to his love of hearts for him by giving him and his kindness. Hearts, by giving, satisfy the people of time, with good management, and putting things in their places. The third: It is the land of creation and the Creator until the land of the people of Heaven ".

Although Al-Akbari mentioned these aspects, he agreed with the meaning that Ibn Jinni intended, and he notes that in his saying: "What Abu Al-Fath said," meaning that this lover is not like all the interesting beloved ones, but he loves this majesty with his worth and the sublime of his matter, for he 
possesses the hearts and he is the correct one. "() AlAkbari responded to the text of Al-Mutanabi, as well as to the text of Abu Al-Fath, so his reading was consistent with the reading of Abi Al-Fath.

Another reader, al-Mu'taraz responded to the text and matched his horizon with that of Ibn Jinni when he said: "He wants that this praised one, unlike all other dear ones, is to possess the hearts of the lovers, and this is the king of heaven here from its extravagances and extremes."

It is worth noting that most of the readers Al Wahidhi, Al Akbari and Al Mutaraz - in their reading of this text did not bring a new reading, and they did not have a new horizon of expectation, but adhered to what Ibn Jinni provided, and for this there is no multiplicity of readings of the text of AlMutanabi. Between the reciter and the text, the text of Al-Mutanabi says:

\section{They found him baffled in a striking shield Meticulous epithelioid}

As this text received a number of readers, and their expectations and cultural data coincided with the language and rhetoric of the text of AlMutanabbi, and among these readers: Ibn Jinni, AlWahidi, and Abu Zakaria. This appears in Ibn Jinni's reading when he said: "His saying (a shield struck): a good metaphor, meaning: he had pressed a shield from beating him to surround him as a shield surrounds his body. Heroes are repelled from him as well as shields "

It appeared in Ibn Jinni receiving two aspects: the first: he stood on the rhetorical side when he favored the metaphor, describing it as (good), showing the justifications for good. The other side, which is linguistic, is explained by the meaning.

The same is the case with al-Wahidi when the meaning of the text coincides with his culture and his linguistic and poetic knowledge and appears in his saying: "The one who has no shield against him, and he wanted: that whoever strikes him with the sword will protect him, and when he made that a shield, he made it delicate weaving, even if there was no weave, or quasi-strings. The minute on his sword was meticulous weaving, and for this he said: The edges of the edges were inflamed, because he wanted the sword with which fire was burning.

His reading was an interpretive reading, as he explained the meaning that the poet wanted, as well as the justification that made the poet use a word instead of another word as he used the word (shield) while he wanted (sword).

And when we turn to Abu Zakariya as well, who is one of the readers whose horizon and previous meanings he carries in his mind regarding this poetic genus with the text of Al-Mutanabi, he approves of the meaning of this text by saying: "He mentioned the shield. An adjective for beating, as the shield was added to it, as it is said: "So-and-so is in the cold of praise." It is permissible to make (Sabbagh) an adjective for cold and praise, if one of them is related to the other does not refrain from describing the beating with precision of tissue and inflammation of the margins, because this term is specific Rather, it is good because it has made the shield removed from what can be weaved, and that it has a hem, because the zebrafish is the origin of the shield, just as spinning is the element of the garment.

And when we turn to Abu Zakariya as well, who is one of the readers whose horizon and previous meanings he carries in his mind regarding this poetic genus with the text of Al-Mutanabi, he approves of the meaning of this text by saying: "He mentioned the shield. An adjective for beating, as the shield was added to it, as it is said: "So-and-so is in the cold of praise." It is permissible to make (Sabbagh) an adjective for cold and praise, if one of them is related to the other does not refrain from describing the beating with precision of tissue and inflammation of the margins, because this term is specific Rather, it is good because it has made the shield removed from what can be weaved, and that it has a hem, because the zebrafish is the origin of the shield, just as spinning is the element of the garment.

\section{I spend as I wish \\ The king and the channel are red}

The text was identical to what Al-Wahidi was expecting from Al-Mutanabi, showing the meaning intended by saying: "He wants to be an owner of himself capable of controlling it and disposing of it on its supply, not being overcome by himself on something he does not want, and he is patient, persevering himself in his hate war if the spears give thanks to blood.". And this reading of rhetoric had a great presence in it, even though the Wahdi. He did not refer to this, except that the reading he presented is poured into a metaphor. There are two metaphors: the first refers to the poet's strength and his possession of the reins of himself. As for the other metaphor, it appears in his saying: (The canna is red) in his patience with the hate of war, and these two metaphors are in a semantic field.The text also came in line with what Ibn Adlan was expecting from the poet, so the language of the text and the poet's style were identical to the cultural stock in the mind of the recipient - Ibn Adlan - The poet did not deviate from what is unfamiliar with what Ibn Adlan knows about him. Among them, Ibn Adlan explained the meaning intended by saying: "He is capable of himself, not defeating him over something he does not want, because he is the owner of it and controls it 
at the time of fear if the spears are red with blood, when meeting the heroes."

It can be said that the response was not between the recipient and the text only. Rather, the readers 'horizons were similar, namely Al-Wahidi and Ibn Adlan. What Ibn Adlan's reading is nothing but the same reading of al-Wahidi with the introduction and delaying some speech.

From the foregoing, it seems that every reader gave a form to the text from his poetic experience and critical culture, as Claire assumes that the form of the text is not determined by the text itself, but rather determined by the reader from the regulations that he applies qualitatively to the text, and this means that the reader does not come to the text empty-minded and approaches the text from Without preconceptions or references that refer to it in his reading.

There are readings that take from the reading of the commentator as a reference to which the reading that was present in the reading response is used by the readers of Abi Tammam's text:

And a fender of longing he is gifted by passion

To the fancy son of the eyes, a goddess

As both Al-Sowi and Ibn Al-Mastoufi responded to his text, it came in accordance with what the readers had in mind of prior knowledge of the meanings of the poet and his poetic style, including Al-Sawy in saying: "He likened the place of his meeting with his loved ones, and his manipulation of them with a battle, which is a subject of war. That is, not in a battle of war (He gave him) a distraction to the battle. Passion: means: He helped him with passion and love, and his saying: (To the one with passion) means himself. Weakness of the mournful (). Al-Sowi's response to the text is evident in his commentary readings - the commentary - as he commented on the verse by mentioning the vocabulary contained in the text with an explanation of their meanings.

A. Likewise, Ibn al-Mastufi identifies his horizons and expectations with the text, so he said: "The narration is what Al-Suly narrated, and the context of the expression in the two verses indicates its authenticity. Al-Soli text and indicated its authenticity. It did not bring a new horizon. In fact, it is the horizon of another reader who has taken from him as a reading tool, so the horizon and expectation precede his reading.

B. Breaking the horizon of expectation disappointment (lack of response between text and recipient agreed) is: There is a standard used by the recipient to know what changes happen in the foundations of the receptive structure, which is defined as: "the concept that the recipient builds to measure interpretations or changes that occur in the structure of receiving throughout history."

The reference to this concept, which is said to him: disappointment of waiting, was taken by Yos from Karl Popper, who pointed out: "The main factor in the completion of any scientific project in particular or in any human experiment in general is the disappointment of waiting, considering that when we conclude that our assumptions are wrong, we are At that time, we are more prepared to interact with reality."

Yaws believes that the concept of disappointment in waiting is not limited to the aesthetic function of literature, but also includes the social function of literature. Literary work may refer to disappointing questions for the public regarding politics or religion, as well as employ aesthetic forms that have not been previously considered.

And that the concept of disappointing or breaking the horizon of waiting leads the reader to change his horizon, either to a higher level so that the reader completes the literary work, or to his rejection and denial of the work. Among the works that disappointed waiting readers was the free verse movement, as poetry moved from half weight to free weight, and also the work of Nizar Qabbani during his transition from the stage of spinning poetry to the stage of political poetry.

And when we turn to this concept in Kitab al-Nizam, the reading of Al-Sowali, Al-Khawarzanji, and Al-Marzouki appears to us as Abi Tammam said:

\section{I still look under the mounds of Mina}

One day, your face is like your face white

This text was interpreted by both Al-Suwali and Al-Khawarzanji, as their horizons of expectations coincided with the text, and Al-Kharazinji also agreed with Al-Sowi's saying, except that Ibn AlMistoufi did not agree with Al-Sowali and AlKharizanji in interpreting this text, and he received it on the other hand according to his cultural stock, and here there was disappointment with Ibn Al-Mastufi From the text of Al-Sawi and the text of AlKharazinji, especially in the interpretation of the word (with your face), which was interpreted by AlSuwali and Al-Kharizanji in the sense of whiteness. As for Ibn Al-Mustawfi, he interpreted it (with glory and honor), seeing that the purpose of the first word (with your face) is glory and honor, not the color of the face, so Aba Tamam wanted to see a day of glory and strength like the white face of Mamdouh.

Al-Marzouki's waiting - not responding was also disappointed by the reading of this text by 
al-Suwali and al-Kharizanji, but he agreed with Ibn al-Mastufi that the intended meaning (in your face) is glory and honor. He says: I still wish you and your place and your face one day as white as your face, I am for him and I took my chance in him. He means by that: to deliver him to the Caliph.

The effectiveness of the text is achieved by the amount of breaking the horizon of readers 'expectation." Yaws emphasized that good literary effects are those that increase the audience's expectation with disappointment, as other effects that satisfy their waiting horizons and meet the desires of their contemporary readers are very ordinary effects that usually only use existing models in construction and change. They are modelling that readers are used to. "

This is what Yaws called for, it appears in the saying of Al-Mutanabi:

And increased caution on the aelic

He distinguishes wasting from facts.

In this text a waiting disappointment occurred - a break in the horizon of expectation - but this disappointment was not between the reader and the text, rather it occurred between one reader and another, that is, between the words of Ibn al-Mastufi and the saying of al-Wahidi who introduced him to read this text. While Al-Wahidi said in this text: "AlAqiq is a type of crow strikes the proverb in caution with a crow, so it is said.

For al-Wahidi has broken the horizon of Ibn al-Mastufi's prediction; Because Ibn Al-Mastufi was not expecting from him this reading that the text did not concern. The text mentions the magpie and seeks thievery with it and not caution, as Ibn al-Mastufi said: "Rather, the one who made the magpie from the ravens, so that his attribution is correct for him, is correct, because the Arabs set the example in caution in the West. In the thieves, it is said: a thief from a magpie, and a steal from a magpie. Abu AlGhammash al-Hanafi said:

I was born with the weight of a stick Thief and more perverted than kandash

For Ibn al-Mastufi, in order to recommend the correctness of his reading, he cited another poet's verse to prove the correctness of the meaning he meant by the word magpie, as every literary work usually carries to the reader a system of expectations, rules and signs that include previous texts or previously read things, and therefore literary work does not It can be created out of a vacuum devoid of the residues of previous texts with which it may participate in sex, but it carries visible and hidden signs and references and refers to things that have been read before, which creates a certain pattern for the audience and pushes it to evoke its aesthetic experience.

For this reason, Ibn al-Mistufi received the text and his response to it, it was more mature and deeper than the one who presented his reading devoid of poetic evidence or proverbs that support the validity of his saying. This approach was present, and some readers responded to it, and others did not. In the words of Abu Tammam:

And the abstinence of longing is given by passion

To the fond of the eyes with the vinegar of the eyes

As everyone responded to this text: Al-Sawi Ibn Al-Mastoufi, except that some of the readers did not respond to the horizon of his expectation with the text, and he did not expect what the poet brought with this text, so he reproached him. Because he came in this meaning, and these vocabulary, and among them: Al-Marzouki, which occurred between him, and between the text is disappointment waiting, and that is in his saying: "The narration (He dedicates him to the one with love) and if Abu Tammam helped the love and the love of the beloved, he would not say (and he is a fool of longing) And if the narration was as it was claimed, his saying (he was gifted with love) would have no benefit, because the addition, if it is possible and the opportunity to meet between the two lovers, if taken advantage of, is not from the act of love, so he makes the gift for him.

Marzouki was disappointed in the meaning of Abi Tammam's house, and he blamed him for his method of repeating the word love in the house, which in one sense made the house not good. AlMarzouki said in that: "Nevertheless, repetition of passion disgraces the home, and it is one meaning.

Likewise, the Al-Amidi was disappointed in waiting for the text of Abu Tammam, and he did not respond to it. That is why Al-Amidi said: "(The host of the longing) he wants a place in which he has visited the Ka'ib, whom he mentioned. And there is a question: It is to say: If the visit and the meeting take place in a place, then this will fall in the longing, so it is not a first battle for the connection. A battle of longing after that situation that was spent, he never longed for that place that he mentioned. "() Seeing that Aba Tammam did not reach in his text the meaning that he wanted to convey to the reader and the recipient, the poet made a mistake when he made a visit and a meeting in that place and that the visit and the meeting fall from longing.

As for Al-Mubarak bin Ahmad, after there was a response between his horizon and the text of Abu Tammam, but the text of the Al-Amadi broke the horizon of his expectation of that, he responded to the Al-Amidi, "reinforcing his response with poetic 
evidence that shows the authenticity of Abu Tammam's saying:"The addition, if it is possible, is not from an act of passion, wrong. Rather, it is only from an act of passion."

I did not visit you on purpose, but with a passion Where the heart loves, the man loves it.

I did not visit you on purpose, but with a passion Where the heart loves, the man loves it

So, Abu Tammam wanted: that desires carried these sons, the eyes of the lepers, that they would visit him ".So, he relied on previous texts in stating the meaning, because the horizon of expectation for Yaws depends on intertextuality, for the literary text does not come from a vacuum, but rather is a collection of a repository consisting of cultural knowledge and aesthetic values that the reader stored while reading the previous texts, and this stock is what controls the recipient's perception and guides in his first reading of the text, as Yaws calls it, the stage of aesthetic perception.

Among the texts that disappointed some readers were waiting for the text of Abu Tammam, who said:

Then he stretched out over the mouth with a hurricane

A resolute opinion and an empty soul

The horizon of al-Ma'ari did not coincide with the text of Abu Tammam, because he did not expect from Abu Tammam these analogies contained in his text. Because Arab culture, especially poetry, does not like similes that are far from similes, as AlMaari said about this text: "And we do not know that someone before al-Ta'i said: a soul of space and this art of speech was his purpose and purpose. An analogy to something other than his instrument. It is narrated (on earth).

And that this text broke the horizon of AlMaari's expectation because of the similes contained in it, which led Al-Maari to reject it.

Just as these readings were present among the readers of the month of Abu Tammam, they were also present in the reading of Al-Mutanabi's poetry, among the readings that showed the congruence or lack thereof between the text and the expectation horizon of the reader's House readings Al-Manabí:

People if they meet Uday as if The weapon of those who met the dust of the sepals

If this text coincides with the horizons of expectation by Ibn Jinni, Abu Al-Ala and Al-Wahidi, then Al-Sharif Al-Murtada broke the text of Ibn Jinni the horizon of his expectation, so he did not expect from Ibn Jinni this reading of the text of AlMutanabi, so Al-Murtada said: "He mentioned Ibn
Jinni's saying ... this is not correct because the slahabs are the longevity of horses and people, so it is permissible to want the slahab: the long prairie, far from dangers, and he singled it out for that, because its dust disperses and does not meet because of the distance of its diameter and the length of its range. Poetry is based on a metaphor, and when the term "slahab" was carried at home on the length of the horse, it was not good to show its abbreviation by describing the dust.

It can be said that Al-Sharif Al-Murtada opposed Ibn Jinni in the term Al-Salahab. Whereas Ibn Jinni singled it out for tall horses, as for Sharif Al-Murtada, he thinks that it is not specific to horses, it is possible to call the longness of people, or the poet wanted long prairie. And here he did not match the horizon of his expectation with a reciter's reading and not with the poet's text, for his horizon was compatible with the text, but he did not agree with the reciter Ibn Jinni.

As for Ibn al-Mastufi, his waiting horizon did not coincide with the reception of al-Sharif alMurtada, and he was disappointed in what was expected of him, so he said: "And his saying - may God be pleased with him - is permissible to want the prairie sahlhab ... This is not controlled by a little or a large number, so it is not correct to be described by one of them so that it comes out of what he wanted.If he meant by dust what the horses stirred in the prairie, he returned to what he denied to Ibn Al-Fath, and increased an increase that is not indicative in the house. There is no need in this regard if he makes it what the horse stirs up to be in the wild

Ibn al-Mistoufi was not satisfied with his response to al-Sharif al-Murtada, but between the meaning that al-Mutanabi wanted, and he singled out the sahlp intended here: it is the female horse, and that in his saying: "And the slave in the house of Abi al-Tayyib is the plural of Sahlba" for the female first; Because the best of the female running is (submission) and the best of the male is (sunshine), so they mentioned it, so that the dust raised by the female is less than what the male raises. Ibn alMastufi was only compatible with the text and did not agree with another reader, but rather the readers of the text of Al-Mutanabi, and this matter appeared on the following:

It may be replaced by other people

So that the heads of a people and minors may be closed.

Al-Wahidi, whose reading agreed with the text, but did not agree with the reader, Ibn Jinni. As Ibn Jinni broke the horizon of waiting for al-Wahdi, then al-Wahidhi did not expect a scholar who is well versed in the Arabic language and its secrets, so Ibn 
Jinni would come with an incorrect reading, and for the pronoun to return (its change) on the swords and not on the (Roman) intended in this house as (the people And in it Al-Wahidi says: "And this is what we mentioned the meaning of Ibn Jinni's saying: that the pronoun is in (its exchange) for the swords, which is not correct in the language ... and the correct meaning of this verse is that the pronoun is in (its change) for the Romans. : He makes others their place in killing and fighting. Based on this, the word was correct and the meaning appeared, and it is not permissible to accuse (others)."

Others) "().

In order for Al-Wahidi to prove that the return of the conscience in (its change) belongs to the swords - as Ibn Jinni sees - does not fit with the meaning that the poet wanted in his text, and he clarified this and proved to him evidence from the verses of the dear book by saying: "The meaning of your swords is given to a people other than the Romans. This is his saying: (in the people other than them) in the place of the second effect of the switch and the people other than the Romans, and this speech is offensive to the fact that: I changed him for such-and-such that I gave him in place of something he had before this and not in the language his substitution: I gave him the allowance, but I changed it and made for him something else in his place as the Almighty said : And when the sign of a verse switched to the place of a verse [An-Nahl: 101], and when the place of a verse changed the place of a verse [Al-Furqan: 70] and you prepare them to let them eat them, then you return to them.

The reading of the single text varied according to the number of readers, some of them responded to the text, and some of them were disappointed by the text or by another reader's reading of the text, and this disparity is acceptable in receiving. "Because every reading seeks to seek the foundations on which knowledge is based, so it adopts its edifice within a framework of facts and perceptions that define its horizons, through concepts that rearrange them in order to serve the purpose for which it was established ...". The readings of Abi Tammam's text varied between compatibility and lack thereof between readers' expectation horizons and the text:

Rather a clutch with the instructions included On its aftershocks both in the beginning and in the wake.

Since there was no response between the Amidian horizon and the text, rather disappointment occurred (or the horizon of expectation was broken). This can be confused with the saying of Al-Amedi: "It is from what he said, his name is" Al-Nassbaha "with forgetting." [Al-Alaq: 15] and blasphemy with something is to be taken and attracted by an attraction in it of violence. He should have said: By means of firmness and determination. As for (the command) it is not useful.

Al-Amadi - here - was disappointed to wait for him from Abi Tammam's texts. Because he was one of the conservative critics, and he tended to print, in poetry, and not to workmanship or sophistication, so he did not tend to Abu Tammam. "Because Abu Tamam is very impious, the owner of the characteristic, and he detests words and meanings, and his poetry does not resemble the poems of the early generations, nor in their style, because of its distant metaphors and generative meanings, it is to be in the space of Muslim Ibn Al-Walid and whoever follows his example - more deserving and more like".

As for Ibn al-Mastufi, his expectation horizon coincided with the text of Abu Tammam, but he broke the horizon of his expectation from the Amidian text for the sake of this. I do not win, and it is better than assertiveness, because firmness: the introduction of confidence, and Abu Tammam, and if he had asked for what he requested from his sides, he is not trustworthy, and that assertiveness is the same thing that Abu Tammam mentioned (). Ibn alMustawfi did not agree with al-Amdi in his reading. Because he sees that he criticizes Aba Tammam's texts in a fanatical manner. In the end, the horizon compatibility or lack thereof is related to the reader and the previous ideas and information it bears about the author's writing style, and the literary gender to which he is presented reading, the style of the text is one and does not change over time, the more there is compatibility between the text and the recipient, if the author changes his writing style, breaches the rules of literary writing, or changes the techniques and styles of the text from what it was previously, a breach occurs between the horizon of the text and the horizon of the reader. The reader collides with a new style that does not carry previous information in his mind, which forces him to resort to interpretation in order to explain the meaning of the texts.

\section{Second. The Aesthetic Distance}

The aesthetic distance, or as it is called (the return), and Yaws defines it as "the distance between the prevailing horizon of expectation and the new literary effect that its reception can lead to (a change in the horizon), whether it goes to opposing familiar experiences, or to make other, unprecedented experiences open their way to consciousness".

The aesthetic distance is close to the concept of fairness, and even appears as a new formulation of this concept in structural poetry, and the aesthetic distance in literary work - impact - is dependent on 
the extent of the text violating the reader's horizon and expectations ().

The aesthetic distance is defined as: "the distance existing between the appearance of the literary effect itself and the horizon of waiting for it. This distance can be obtained by extrapolating the reactions of the readers on the effect, that is, through those critical judgments that they make".

The aesthetic distance is the criterion for judging the aesthetic value of the literary work. It shrinks, and this distance becomes narrow when the work becomes familiar with the consciousness of the recipient. So, he is not able to build a new horizon, then the literary work will be closer to books that have nothing to do with the spaces of art and - The aesthetic distance in the house of Abi Tammam:

And abused longing is dedicated by passion

To the fanciful son of the eyes.

\begin{tabular}{|c|c|c|c|c|}
\hline No. & Text Reading & Response Type & $\begin{array}{l}\text { Aesthetic } \\
\text { Distance }\end{array}$ & $\begin{array}{l}\text { Aesthetic } \\
\text { Value }\end{array}$ \\
\hline 1 & Soli & Match & Narrow & Tacky \\
\hline 2 & Amadi & Waiting disappointment & Wide & Good (Artistic) \\
\hline 3 & Marzouki & Waiting disappointment & Wide & Good (Artistic) \\
\hline \multirow[t]{2}{*}{4} & \multirow{2}{*}{$\begin{array}{l}\text { Al-Mubarak bin } \\
\text { Ahmed }\end{array}$} & Match with the text of Abi Tamam & Narrow & Tacky \\
\hline & & $\begin{array}{l}\text { Waiting disappointment with the Amadi } \\
\text { text }\end{array}$ & & Good (Artistic) \\
\hline
\end{tabular}

In Abi Tammam's text, the readings varied, and the readers 'horizons were between congruence and mismatch, so the aesthetic distance of the text differed according to the readers. In congruence in literature. This distance expands when the work includes shifts and ambiguities beyond the expectations of the recipient in this or that work or when the recipient can build a new horizon for work.

Aesthetic distance applications:

To apply the concept of aesthetic distance to the texts of Abu Tammam and Al-Mutanabi, it is necessary to mention the fur of the text, and to indicate the type of response if that response matches the reader's horizon with the text, or a disappointment in it, and pay attention to the aesthetic distance on the one hand in that it is narrow or wide, and finally standing When the aesthetic value according to the criteria of (YOS) in the art of the text is (good), or that the text is vulgar, as follows:

People, if they meet Uday, it is as though

Weapon found the Dust of the Slaughterhouse.

\begin{tabular}{|l|l|l|l|l|}
\hline No. & Text Reading & Response Type & $\begin{array}{l}\text { Aesthetic } \\
\text { Distance }\end{array}$ & $\begin{array}{l}\text { Aesthetic } \\
\text { Value }\end{array}$ \\
\hline 1 & Makhzoumi & Match & Narrow & Tacky \\
\hline 2 & Genie son & Match & Narrow & Tacky \\
\hline 3 & Abu Ala & Match & Narrow & Tacky \\
\hline 4 & The one Al- & Waitch & Wide & $\begin{array}{l}\text { Good } \\
\text { (Artistic) }\end{array}$ \\
\hline 5 & $\begin{array}{l}\text { Sharif } \\
\text { Murtada }\end{array}$ & $\begin{array}{l}\text { Good } \\
\text { (Artistic) }\end{array}$ \\
\hline 6 & Ibn Al-Mistoufi & $\begin{array}{l}\text { Match with The Text, Disappointment From Al- } \\
\text { Murtada's Text }\end{array}$ & Wide & Shaintment From Ibn Jinni's Text \\
\hline
\end{tabular}

The readers of Al-Mutanabbi's text match their horizons with the text, so the aesthetic distance was narrow, which led to the vulgarity of the artistic value, but the aesthetic distance expanded and the - The aesthetic distance in Abi Tammam text:

horizons, the aesthetic distance was narrow, while in mismatch the aesthetic distance expanded and the aesthetic value became artistic.

- The aesthetic distance in Al-Mutanabi text:

I still watched under the dead of semen

One day your face is like your face white.

\begin{tabular}{|l|l|l|l|l|}
\hline No. & Text Reading & Response Type & Aesthetic & Aesthetic \\
\hline
\end{tabular}




\begin{tabular}{|l|l|l|l|l|}
\hline & & Distance & Value \\
\hline 1 & Al-Khazanji & Match & Narrow & Tacky \\
\hline 2 & Genie son & Match & Narrow & Tacky \\
\hline 3 & Marzouki & Match With The Al Mubarek & Narrow & Tacky \\
\hline 4 & $\begin{array}{l}\text { Al-Mubarak bin } \\
\text { Ahmed }\end{array}$ & $\begin{array}{l}\text { Awaiting Disappointment with The Text of Al- } \\
\text { Souly And Al-Khaznaji }\end{array}$ & $\begin{array}{l}\text { Good } \\
\text { (Artistic) }\end{array}$ \\
\hline
\end{tabular}

In the text of Abi Tammam, the aesthetic distance differed between narrow and expansion. In the reading of both al-Khawarzanji and Ibn Jani, the aesthetic distance narrowed, so the aesthetic value of - The aesthetic distance in Al-Mutanabi text: the text was poor. As for the reading of Al-Marzouki and Ibn Al-Mistoufi, the aesthetic distance expanded and the artistic value of the text became good.

They found him bare in a striking shield

Meticulous inflammatory marginal

\begin{tabular}{|l|l|l|l|l|}
\hline No. & Text Reading & Response Type & Aesthetic Distance & Aesthetic Value \\
\hline 1 & Genie son & Match & Narrow & Tacky \\
\hline 2 & Abu Zakaria & Match & Narrow & Tacky \\
\hline 3 & Al Wahidi & Match & Narrow & Tacky \\
\hline
\end{tabular}

Al-Mutanabi's text - here - is read by four

narrow and the artistic value is trite, in order to match readers, in which the aesthetic distance appears the readers 'horizons with the text.

- The aesthetic distance in the text of Abi Tammam:

Rather, a clutch with the help of the matter is included

On its aftershocks both in the beginning and in the wake.

\begin{tabular}{|l|l|l|l|l|}
\hline No. & Text Reading & Response Type & Aesthetic Distance & Aesthetic Value \\
\hline 1 & Amadi & Waiting disappointment & Wide & Tacky \\
\hline 2 & Al Mubarek & With text (match) & Narrow & Good (Artistic) \\
\cline { 3 - 5 } & $\begin{array}{l}\text { With the Amadi text (waiting } \\
\text { disappointment) }\end{array}$ & Wide & Tacky \\
\hline
\end{tabular}

The text of Abi Tamam - here - raises two readings, for in the first reading of al-Ami the disappointment of waiting between the reader and the text appears, which led to an expansion of the aesthetic distance, but in the second reading of Ibn alMustawfi, the aesthetic distance of the text varied

- The aesthetic distance in the text of Abi Tammam:

He stretched out a hurricane on the mouth

A resolute opinion and an empty soul.

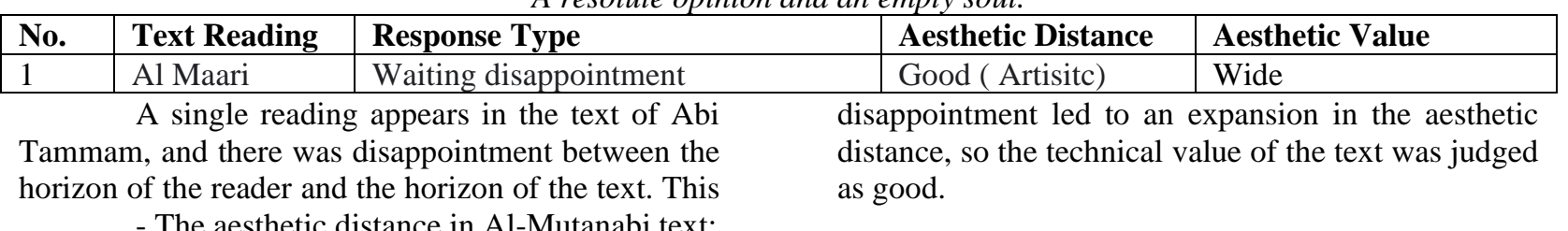

- The aesthetic distance in Al-Mutanabi text:

according to his reading, so his horizon may correspond to the text, so the aesthetic value of the text It became vulgar, as for reading it on the Amadi text, a disappointment occurred, and the aesthetic distance of the text expanded.

I spend as I wish

Its owner and the canal are red.

\begin{tabular}{|l|l|l|l|l|}
\hline No. & Text Reading & Response Type & Aesthetic Distance & Aesthetic Value \\
\hline 1 & Al Wahidi & Match & Narrow & Tacky \\
\hline 2 & Abin Adlan & Match & Narrow & Tacky \\
\hline
\end{tabular}

Two readers appear in this text, agreeing on the response that was identical, and the aesthetic distance appeared narrow in it, killing the aesthetic value of the text reader, because it is trivial. From the 
above, it can be said that there is a discrepancy in the readers of the texts of Abu Tammam and AlMutanabi, in terms of their number, as it rises to six, to descend to one reader, while the response, the congruence appears more than a disappointment in

\section{CONCLUSION}

The reception of readers of Abi Tammam and Al-Mutanabi's poetry varied between response and non-response. As there appeared some texts that met the expectations of the readers, and there was no breach of their expectations, but there were other texts that disappointed their recipients. It came inconsistent with their expectations, as some rules and methods were violated, which made the reader in a state of disappointment and surprise, and that disappointment in waiting, according to Yaws, is what gives the texts an aesthetic value. Because it makes the reader an interpreter and an administrator, and then a producer of the text, and the aesthetic value of the texts is linked to the aesthetic distance, the more the aesthetic distance is wide, the aesthetic value of the texts is good, or if the aesthetic distance is narrowed, the value of the texts becomes vulgar.

\section{REFERENCES}

[1] See: The Receptivity Theory (Origins and Applications), Bushra Moussa Saleh, 1st Edition, Arab Cultural Center, Casablanca Morocco, 2001: 45.

[2] Receiving Theory (Critical Introduction), Robert Holbe, Tr (Ezz El-Din Ismail), Edition 1, The Academic Library, Cairo Egypt, 2000: 104.

[3] See: Receipt Theory (Critical Introduction), Robot Hulpe: 104.

[4] The same source: 104.

[5] Receptivity theory (origins and applications), by Bushra Musa Salih: 45.

[6] An introduction to the theory of receptivity, Hafiz Aliwi, Journals of Criticism Signs, Mag (9), P (34), Saudi Arabia, 1999: 88.

[7] Towards an Aesthetic Receptivity (History of Literature Challenge to Literature Theory), Hans Robert Yaws, Tr (Muhammad Musaadi), 1st Edition, Al-Naya Studies and Publishing, Beirut - Lebanon, 2014: 63 .

[8] Starobansky: "A French critic who was one of the most important critics of the twentieth century, and he was also a philosopher, and he wrote the introduction to Yous's book (Towards an Aesthetic Receptivity) in French" (Source on the Internet: alittinadiae.).

[9] () The Essays of Receptivity Theory: Between Cognitive References and waiting, as is the case with the aesthetic distance that was narrower. Its capacity is one-time, and in relation to aesthetic value, it is more vulgar than its technique to readers.

Procedural Practice, Muhammad AbdelBashir, The Generation of Literary and Intellectual Studies, P (4), Lebanon, 2014: 90

[10] In the narration of al-Tabrizi (its ghebriatha): 50 (The diwan of Abi Tamam al-Tabrizi).

[11] The Order in Explaining the Poetry of AlMutanabi and Abu Tammam, Ibn AlMistoufi Al-Arbli, Tah (Khalaf Rashid Numan), First Edition, House of General Cultural Affairs, Baghdad - Iraq, 1998: 6/65, The Divan of Abi Tamam, Al-Khatib AlTabrizi, Tah (Muhammad Abda) 4th Edition, Dar Al Ma'aref, Egypt, 1999: 2/50.

[12] The same source: 65-66, Abi Tammam Diwan: $2 / 50$.

[13] The same source: 66.

[14](Al-System): 6 / 66-76, Sharh Al-Marzouki: 89.

[15] Law: 6/335, Diwan al-Mutanabi: 1/3.

[16] Law: 6 / 335-336, interpretation: 1/34.

[17] System: 1/36, Explanation of Al-Wahidi: 1395.

[18]Law: 1/336, Explanation of Al-Akbari to Diwan Al-Mutanabi: 1/3.

[19] System: 1/337.

[20] Al-Matruz (439): "He is Abd al-Wahid ibn Muhammad ibn Yahya ibn Ayyub, Abu alQasim known as the embroiderer, a Baghdad poet, a great deal of poetry in praise, satire and spinning, and al-Khatib alTabrizi read to him" (source from the internet: www.wikipedia)

[21] System: 1/377.

[22] Law: 10/12, Diwan al-Mutanabi: 2/209.

[23] The same source: 12, Al-Tafsir by Ibn Jinni: $2 / 287$.

[24]() Law: 10/13, Explanation of Al-Wahdi: 1017.

[25] System: 10/13.

[26] Law: 8/299, Al-Mutanabi Diwan: 2/93.

[27] Law: 8/229, Explanation of Al-Wahidi: 1046.

[28] Ibn Adlan (583 AH-666 AH): "Ali bin Adlan bin Abu al-Hassan al-Nahawi alMawsili. He took grammar and Arabic knowledge from the writers of Mosul.

[29] Seen: An Introduction to the Reader's Response Criticism, Jane B. Tompkins, TR 
(Hassan Nazem and Ali Hakim), from the book Articles in the Public, 1st Edition, New United Book House, Beirut - Lebanon, 2007: 29

[30]Law: 2/185, Diwan of Abi Tamam: 1/138.

[31] (Al-System): 185-186, Explanation of AlSoli: $1 / 238$.

[32] The same source: 187.

[33] Receptivity theory (origins and applications), by Bushra Musa Salih: 47 .

[34] The novel from the perspective of the theory of receptivity, Said Omri, i 1, The Baath Project and Translation Theory Publications, Fez - Morocco, 2009: 33.

[35] See: System: 187.

[36] () See: Concepts of the theory of reading and receptivity, Ruba Abdul-Ridha, Diyala Magazine, P (69), Diyala - Iraq, 2016: 170171.

[37] Abi Tammam Diwan: 2/304, Law 10/94.

[38] The System, A10: 94.

[39] (System: 94-95.

[40] Readings in The Theory of Reading and Receptivity (A Study in the Qur'an Text), Yasser Muhammad Fadel, First Edition, Dijlah, Amman - Jordan, 2016: 104

[41] Al-Mutanabbi Diwan: 2/356, Law: 12/303.

[42] Law: 12/303, Explanation of Al-Wahidi: 968.

[43] Law: 12/303.

[44] The novel from the perspective of receptivity theory, Saeed Omari: 32.

[45] Abi Tammam Diwan: 1/138, Law: 2/185

[46] System 22/186.

[47] Same source, the same newspaper.

[48] System: 2/186.

[49] System: 2/187.

[50] See: The Essays of Receptivity Theory: Between Cognitive References and
Procedural Practice, Muhammad AbdelBashir, The Generation of Literary and Intellectual Studies Journal, P (4), Lebanon, 2014: 90.

[51] Abi Tammam Diwan: 4/17, Law: 1/276.

[52] Same source: the newspaper itself.

[53] Al-Mutanabbi Diwan: 1/153, Law: 4/226.

[54] Law: 4/227.

[55] System: 4/228.

[56] Same source: the newspaper itself.

[57]Al-Mutanabbi Diwan: 2/99, regulation: 8/316.

[58]Law: 8/317, Explanation of Al-Wahidi: 1470-1471.

[59] Law: 8/317.

[60]Readings in The Theory of Reading and Recitation (A Study in the Qur'an Text), Aysar Muhammad Fadel: 98.

[61] Abi Tammam Diwan: 4/550, Law: 3/197.

[62] Law: 3 / 197-198.

[63] Al-Moazazah, Al-Amadi, Tah (Mr. Ahmed Saqr), 4th ed., Dar Al Maaref, Cairo - Egypt, 1119: 1 / 4-5

[64]Law: 3/198.

[65]Al-Adoul: Aesthetic Dislocation: Revater defines it as: "a breach of the rules and resorting to what are scarce formulas at another time." Style and stylistics, Abd alSalam al-Masadi: 103.

[66] Toward an Aesthetics of Receptivity, Hans Robert Yaws: 66.

[67] Receiving and Maqamat: 35.

[68] See: Jamaliyat al-Talqi (for a new interpretation of the literary text), Robert Yaws, Tr (Rachid Benhadou), Edition 1, Dar Kalima, Beirut-Lebanon, 2016: 59-60

[69] Abi Tammam Diwan: 1/138, Law: 2/185

[70] Al-Mutanabbi Diwan: 1/153, Law: 4/226.

[71] Al-Mutanabbi Diwan: 2/93, Law: 8/299. 